
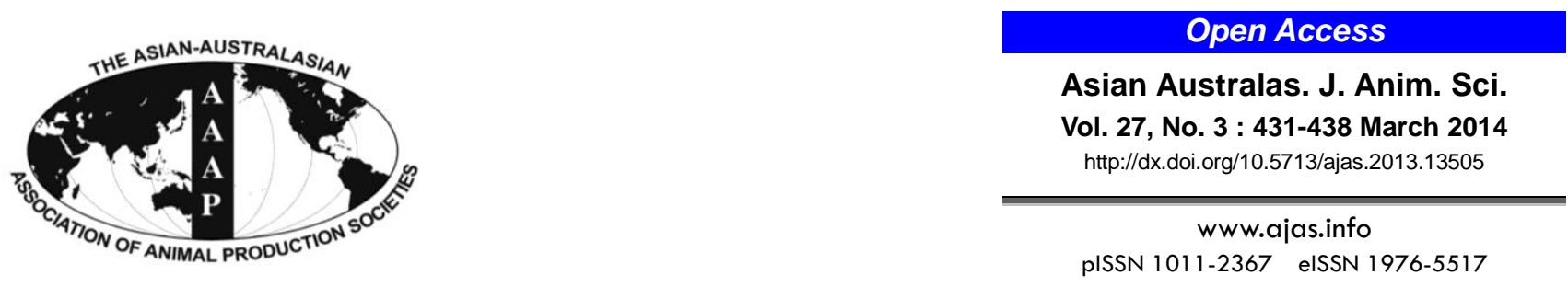

\title{
Piglets' Surface Temperature Change at Different Weights at Birth
}

\author{
Fabiana Ribeiro Caldara*, Luan Sousa dos Santos, Sivanilza Teixeira Machado, Marta Moi, \\ Irenilza de Alencar Nääs, Luciana Foppa, Rodrigo Garófallo Garcia, and Rita de Kássia Silva dos Santos \\ Federal University of Grande Dourados, College of Agrarian Sciences, Dourados, MS, Brazil
}

\begin{abstract}
The study was carried out in order to verify the effects of piglets' weight at birth on their surface temperature change (ST) after birth, and its relationship with ingestion time of colostrum. Piglets from four different sows were weighed at birth and divided into a totally randomized design with three treatments according to birth weight (PBW): T1 - less than $1.00 \mathrm{~kg}, \mathrm{~T} 2-1.00 \mathrm{to} 1.39 \mathrm{~kg}$, and T3 - higher than or equal to $1.40 \mathrm{~kg}$. The time spent for the first colostrum ingestion was recorded (TFS). Images of piglets' surface by thermal imaging camera were recorded at birth (STB) and 15, 30, 45, 60, and 120 min after birth. The air temperature and relative humidity were recorded every $30 \mathrm{~min}$ and the indexes of temperature and humidity (THI) were calculated. A ST drop after 15 min from birth was observed, increasing again after sixty minutes. Positive correlations were found between the PBW and the ST at 30 and 45 min after birth. The PBW was negatively correlated with the TFS. The THI showed high negative correlations $(-0.824$ and -0.815$)$ with STB and after $15 \mathrm{~min}$ from birth. The piglet's surface temperature at birth was positively correlated with temperature thereof to $15 \mathrm{~min}$, influencing therefore the temperatures in the interval of 45 to $120 \mathrm{~min}$. The birth weight contributes significantly to postnatal hypothermia and consequently to the time it takes for piglets ingest colostrum, requiring special attention to those of low birth weight. (Key Words: Infrared Thermography, Piglet Weight, Thermal Comfort)
\end{abstract}

\section{INTRODUCTION}

Hypothermia is one of the major cause of neonatal piglets' mortality. At birth, piglet is exposed to drastic changes in the ambient temperature. Considering the physiological temperature in sow's utero, between $38^{\circ} \mathrm{C}$ to $40^{\circ} \mathrm{C}$, immediately after the piglets' birth, whose minimum temperature comfort is around $34^{\circ} \mathrm{C}$ to $35^{\circ} \mathrm{C}$ (Mount, 1959; Manno et al., 2005), they come in contact with a colder environment in farrowing crates, near the comfort range for lactating sow, $18^{\circ} \mathrm{C}$ to $23^{\circ} \mathrm{C}$ (Yan and Yamamoto, 2000; Brown-Brandl et al., 2001). This event triggers the reduction of body temperature soon after birth (Tuchscherer et al., 2000; Pandorfi et al., 2005; Malmkvist et al., 2006).

This process is known as post natal hypothermia and its extension and duration is negatively correlated with the survival chances of the piglet (Tuchscherer et al., 2000).

\footnotetext{
* Corresponding Author: Fabiana Ribeiro Caldara. Tel: +55-6781188114, E-mail: fabianacaldara@ufgd.edu.br Submitted Aug. 15, 2013; Accepted Oct. 7, 2013; Revised Oct. 27, 2013
}

These losses can affect piglet in the ways of as low intake of colostrum, low development, higher susceptibility to disease and more cases of crushing (Pandorfi et al., 2005; Souza, 2007). Nevertheless, there are large individual differences between and within litters, in the success of newborn piglets' recovery (Tuchscherer et al., 2000). The recovery of body temperature to normal physiological values depends on factors such as room temperature, piglet's weight at birth, time required to start breastfeeding and the management adopted in the farm.

Currently, strains of sows intended for breeding are being genetically improved in order to become hyper prolific. Furthermore, changes inherent to management allowed the increase in number of weaned piglets per female per year, from an average 21 to 23 piglet (Mercks et al., 2000) to a level surrounding 28 to 30 weaned piglets per female per year (Antunes, 2007). Consequently, there was an increase of problems related to birth weight and nonuniform litters, contributing to the higher variability in weight between piglets (Sorensen et al., 2000; Damgaard et al., 2003).

Copyright $\odot 2014$ by Asian-Australasian Journal of Animal Sciences This is an open-access article distributed under the terms of the Creative Commons Attribution Non-Commercial License (http://creativecommons.org/licenses/by-nc/3.0/), which permits unrestricted non-commercial use, distribution, and reproduction in any medium, provided the original work is properly cited. 
The lower birth weight predisposes piglets to lower chances of surviving (Van Rens et al., 2005) and this effect is more pronounced in piglets with an average weight less than $1.0 \mathrm{~kg}$ (Quiniou et al., 2002). These piglets have lower levels of body energy supplies, greater sensitivity to cold, take longer to achieve the mammary complex and a lower ability to choose the best teat (Lay Júnior et al., 2002).

The thermoregulatory capacity is directly related to birth weight. Lighter piglets have higher body surface in relation to its weight, and they are, therefore, more likely to be affected by hypothermia (Herpin et al., 2002). Panzardi et al. (2009) found that birth weight and body temperature at $24 \mathrm{~h}$ post-birth are among the best predictors of survival rate during the first postnatal week.

Thereby, this study was carried out in order to verify the effects of piglets' birth weight in individual change on surface temperature after birth, and to determine its relationship with the time required for colostrum ingestion.

\section{MATERIAL AND METHODS}

\section{Local, experimental design and animal management}

The experiment was conducted in a full cycle commercial pig farm, located in Dourados, MS. The city altitude is $430 \mathrm{~m}$, latitude $22^{\circ} 13^{\prime} \mathrm{S}$ and longitude $54^{\circ} 48^{\prime} \mathrm{W}$. The climate is tropical with rainy summer and dry winter.

Litters from four sows, crossbred Landrace $\times$ Large White, were used in the research, all of third farrow. The females were distributed in individual farrowing cells with a total area of about $4.0 \mathrm{~m}^{2}$, provided with protection against crush and a creep was provided with incandescent lamp as a heat source for the piglets.

The production system works with forced synchronization of birth, with an average of six to seven calving per week. Females were induced through the injection of $0.12 \mathrm{mg}$ cloprostenol via SMV, with $24 \mathrm{~h}$ prior to expected date of parturition.

After birth, the piglets were instantly dry with paper towel and received numbers with ink marker. After the rupture of umbilical cord, that occurred naturally, without assistance of the workers, the piglets were weighed and sent for first colostrum ingestion, which was recorded, for each animal. This variable was defined as the first time the piglet breastfed continuously in the same teat for at least one minute.

From the birth weight, the piglets were divided into a completely randomized design with three treatments, which consisted in the ranges of birth weight: $\mathrm{T} 1$ - less than 1.00 $\mathrm{kg}, \mathrm{T} 2-1.00$ to $1.39 \mathrm{~kg}$, and T3 - higher than or equal to $1.40 \mathrm{~kg}$.

\section{Infrared thermography and evaluation of piglets' surface temperature}

Infrared images of all piglets were registered at birth (after performing the cleaning procedure) at 15, 30, 45, 60, 120 , and $180 \mathrm{~min}$ after birth. The thermal images recording was performed using the Termovisor Testo 876-1 Kit Professional equipment, with accuracy of $\pm 0.1^{\circ} \mathrm{C}$, and the images were processed using the Testo IRSoft software Version 3.1 SP2. The emissivity coefficient of 0.96 was used for all body surface of the animal. The average and standard deviation values of temperature of the body surface were calculated using the 30-point temperature selected to represent entire body surface of the animal, or by selecting areas to construct a histogram temperature (Figure 1). The surface temperature of farrowing crates floor was also recorded, using the same procedure and an emissivity coefficient of 0.94 for plastic.

\section{Environment parameters}

The temperature and relative air humidity, inside and outside the farrowing crate were recorded every $30 \mathrm{~min}$, during the experimental period, using a digital thermohygrometer.

Using the recorded values of air temperature and relative humidity, the dry bulb temperature (dbt) and wet bulb (wbt) were calculated via Psicrom program (Roriz, 2003) and after that, the Temperature and Humidity indexes (THI) were determinate by using equation 1 described by Thom (1958):

$$
\mathrm{THI}=0.72(\mathrm{dbtt}+\mathrm{wbt})+40.6
$$

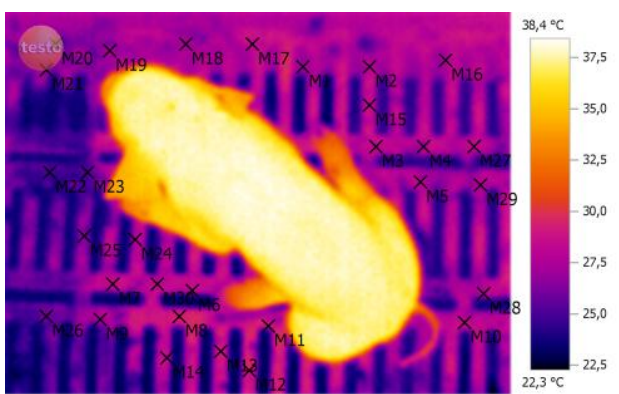

Figure 1. Infrared image recorded at the birth of piglets, and 30 points selected to represent body surface of the animal and farrowing cage floor. 


\section{Statistical analysis}

Variance analysis was applied to the surface temperature data and time to first feeding, using initially the ranges of birth weight and thereafter sows as treatments. The averages were compared by Tukey test at 5\% significance, using SAS 9.2 (SAS, 2001). Spearman correlation analyzes between piglet's weights at birth, the surface temperature over time after birth and time to first feeding were performed.

\section{RESULTS AND DISCUSSION}

The studied variables showed similar data and slight variations in averages combined with low coefficient of variation values $(\mathrm{CV} \%)$, indicating sample precision, except for the time for first feeding (TFS), which presented a considerable variation, and thus showed a higher data dispersion (Table 1).

Observing the piglet weight after two hours old (P120), it was clear that there was a slight change compared to birth weight (Figure 2). There was a decrease in ST after the first 15 min of life, increasing again two hours after. The largest drops in temperature occurred between fifteen and sixty minutes after the birth of piglets (between $2.15^{\circ} \mathrm{C}$ to $5.61^{\circ} \mathrm{C}$, average $3.88^{\circ} \mathrm{C}$ ), normal values $\left(1.7^{\circ} \mathrm{C}\right.$ to $6.7^{\circ} \mathrm{C}$ with an average $2.2^{\circ} \mathrm{C}$ ), compared to reference ranges according to Mendonça (2010).

\section{Environment}

The mean temperature inside the farrowing crate from 10:00 am to $6: 00 \mathrm{pm}$ ranged from $26.3^{\circ} \mathrm{C}$ to $32.5^{\circ} \mathrm{C}$ and the relative humidity ranged from $34.3 \%$ to $47 \%$, reaching highest temperature values and lowest humidity between 3:00 pm and 4:00 pm.

The ideal environment to be provided for pigs varies according age and physiological condition. In the specific case of sows farrowing, there are two animal categories with different comfort temperature ranges: the lactating sow, whose comfort range is $18^{\circ} \mathrm{C}$ to $23^{\circ} \mathrm{C}$ (Yan and Yamamoto, 2000; Brown-Brandl et al., 2001); and the piglet, which comfort range is $30^{\circ} \mathrm{C}$ to $32^{\circ} \mathrm{C}$ (Lima et al., 2011). The increase in internal temperature of farrowing rooms in order to attend the thermal demand of piglets very often disregards the temperature range of comfort for the sow, which can cause heat stress in the female, affecting milk production (Lima et al., 2011), and interfering with the natural process of birth due to heat stress and suppression of secretion of oxytocin. However, this fact was not observed in this study, and no sows in this trial showed problems with dystocia during the birth process, which lasted around 2 to 3 h.

When considering the recommended values of air temperature and relative humidity for piglets in the first week of life, the THI within the thermal comfort ranges from 83.5 to 87.6 , with critical values of THI less than 66.4 , and higher than 92.1. Thereby, calculated values (75.63 to 82.51) were found during most of the time, closer to the thermal comfort zone than to the critical range; however, they were below the ideal ones.

\section{Birth weight effects}

Positive correlations were observed between piglet weight at birth (PBW) and their surface temperatures at 30 and $45 \mathrm{~min}$ after birth, indicating that the heavier the piglet's birth weight, the higher surface temperature during this time interval, and then, the lower drop in surface temperature due to hypothermia postnatal (Table 2, Figure $3)$. Therefore, since the fall of body temperature in the first 60 minutes after birth is observed, the first hours of life in the piglets are critical times for the animal, especially for those with low birth weight.

Hypothermia occurs naturally after birth, in the majority

Table 1. Descriptive statistics of study variables

\begin{tabular}{lccccc}
\hline Variable $^{1}$ & Mean & Minimum & Maximum & SD & VC\% \\
\hline THI & 77.87 & 75.63 & 82.51 & 3.24 & 4.16 \\
PBW & 1.32 & 0.84 & 1.8 & 0.28 & 21.21 \\
STB & 35.94 & 31.26 & 38.59 & 2.55 & 7.09 \\
$\mathrm{~T}_{15}$ & 36.21 & 31.23 & 38.65 & 2.02 & 5.57 \\
$\mathrm{~T}_{30}$ & 35.82 & 32.98 & 38.44 & 1.52 & 4.24 \\
$\mathrm{~T}_{45}$ & 35.91 & 33.38 & 38.29 & 0.96 & 3.62 \\
$\mathrm{~T}_{60}$ & 36.55 & 34.92 & 38.63 & 0.64 & 2.62 \\
$\mathrm{~T}_{120}$ & 37.37 & 35.89 & 38.4 & 32.23 & 1.71 \\
TFS & 52.75 & 12.0 & 130.0 & 0.28 & 61.09 \\
$\mathrm{P}_{120}$ & 1.30 & 0.81 & 1.79 & 21.53 \\
\hline
\end{tabular}

${ }^{1} \mathrm{THI}=$ Temperature humidity index $; \mathrm{PBW}=$ Piglet birth weight $(\mathrm{kg}) ; \mathrm{STB}=$ Surface temperature at birth $\left({ }^{\circ} \mathrm{C}\right) ; \mathrm{T}_{15}=$ Piglet surface temperature 15 min after birth $\left({ }^{\circ} \mathrm{C}\right) ; \mathrm{T}_{30}=$ Piglet surface temperature $30 \mathrm{~min}$ after birth $\left({ }^{\circ} \mathrm{C}\right) ; \mathrm{T}_{45}=$ Piglet surface temperature 45 min after birth $\left({ }^{\circ} \mathrm{C}\right) ; \mathrm{T}_{60}=$ Piglet surface temperature $60 \mathrm{~min}$ after birth; $\mathrm{T}_{120}=$ Piglet surface temperature $120 \mathrm{~min}$ after birth $\left({ }^{\circ} \mathrm{C}\right) ; \mathrm{TFS}=$ Time to first suckle $(\mathrm{min}) ; \mathrm{P}_{120}=$ Piglet weight $120 \mathrm{~min}$ after birth $(\mathrm{kg})$.

$\mathrm{SD}=$ Standard deviation; $\mathrm{VC}=$ Variation coefficient 

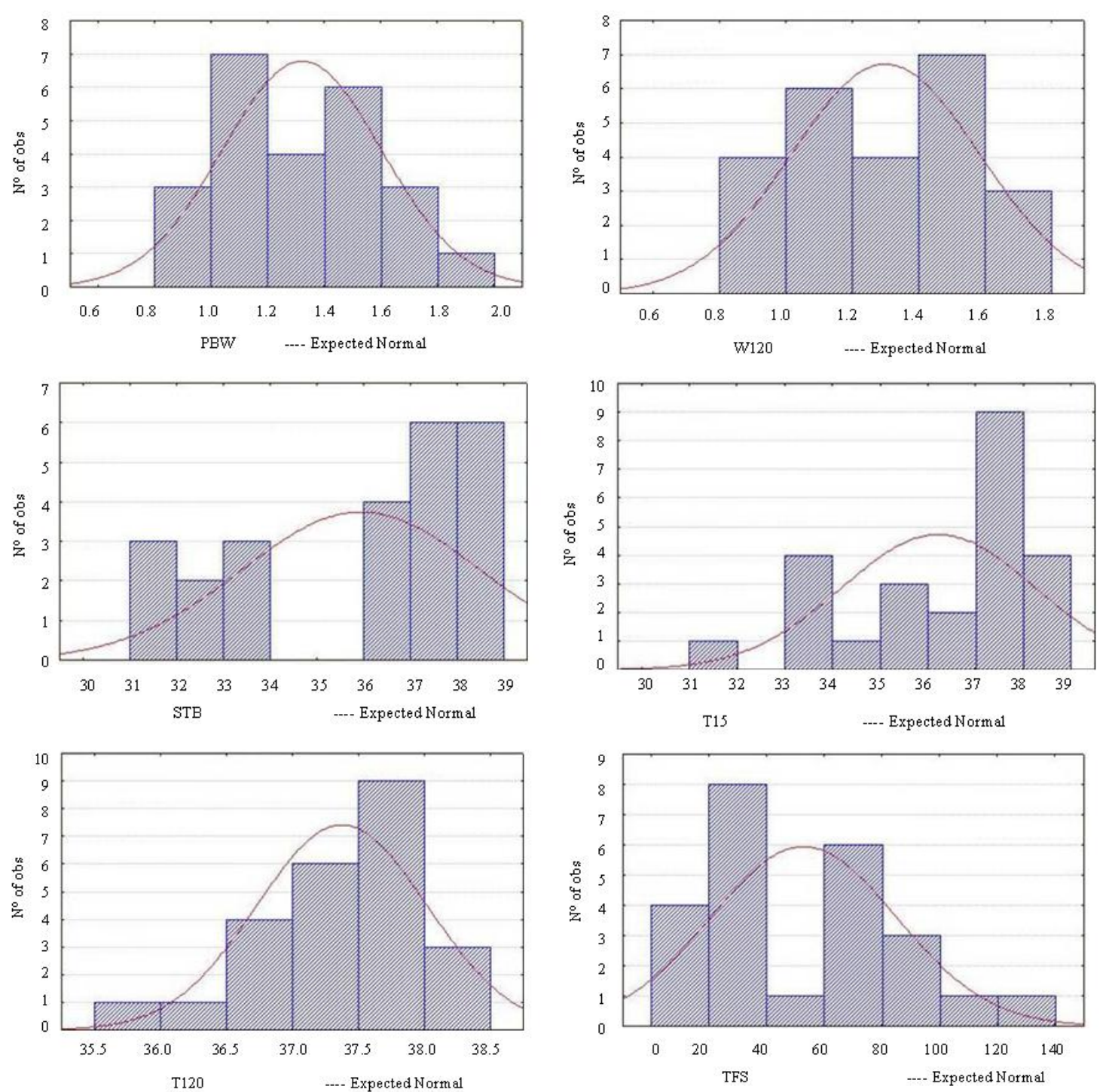

Figure 2. Observed and expected distribution for the variables: piglet birth weight (PBW), surface temperature at birth (STB), time to first suckle (TFS), piglet temperature 15 min after birth (T15), piglet weight 120 min after birth (P120) and piglet temperature 120 min after birth (T120).

Table 2. Spearman correlation coefficient for piglets after two hours of birth

\begin{tabular}{|c|c|c|c|c|c|c|c|c|c|}
\hline & THI & STB & $\mathrm{T} 15$ & $\mathrm{~T} 30$ & $\mathrm{~T} 45$ & T60 & $\mathrm{T} 120$ & TFS & $\mathrm{P} 120$ \\
\hline PBW & $-0.072^{\mathrm{ns}}$ & $-0.051^{\mathrm{ns}}$ & $0.128^{\mathrm{ns}}$ & $0.481 * *$ & $0.473 * *$ & $0.346^{\mathrm{ns}}$ & $0.185^{\mathrm{ns}}$ & $-0.546^{* *}$ & $0.985 * *$ \\
\hline THI & & $-0.824 * *$ & $-0.815 * *$ & $-0.374^{\mathrm{ns}}$ & $-0.537 * *$ & $-0.577 * *$ & $-0.490 * *$ & $-0.248^{\mathrm{ns}}$ & $-0.045^{\mathrm{ns}}$ \\
\hline STB & & & $0.722 * *$ & $0.132^{\mathrm{ns}}$ & $0.220^{\mathrm{ns}}$ & $0.397^{\mathrm{ns}}$ & $0.295^{\mathrm{ns}}$ & $0.229^{\mathrm{ns}}$ & $-0.088^{\mathrm{ns}}$ \\
\hline $\mathrm{T} 15$ & & & & $0.400^{*}$ & $0.390^{*}$ & $0.560 * *$ & $0.345^{\mathrm{ns}}$ & $0.233^{\text {ns }}$ & $0.080^{\mathrm{ns}}$ \\
\hline T30 & & & & & $0.644 * *$ & $0.386^{\mathrm{ns}}$ & $0.339^{\text {ns }}$ & $0.022^{\mathrm{ns}}$ & $0.481 * *$ \\
\hline $\mathrm{T} 45$ & & & & & & $0.720 * *$ & $0.487 * *$ & $0.017^{\text {ns }}$ & $0.484 * *$ \\
\hline T60 & & & & & & & $0.614 * *$ & $-0.056^{\mathrm{ns}}$ & $0.390^{*}$ \\
\hline $\mathrm{T} 120$ & & & & & & & & $-0.130^{\mathrm{ns}}$ & $0.218^{\mathrm{ns}}$ \\
\hline TFS & & & & & & & & & $-0.573 * *$ \\
\hline
\end{tabular}

\footnotetext{
** $p<0.01, * p<0.05,{ }^{\text {ns }} \mathrm{p}>0.05$.
}

$\mathrm{THI}=$ Temperature humidity index; PBW $=$ Piglet birth weigth $(\mathrm{kg}) ; \mathrm{STB}=$ Surface temperature at birth $\left({ }^{\circ} \mathrm{C}\right) ; \mathrm{T}_{15}=$ Piglet surface temperature 15 min after birth $\left({ }^{\circ} \mathrm{C}\right) ; \mathrm{T}_{30}=$ Piglet surface temperature $30 \mathrm{~min}$ after birth $\left({ }^{\circ} \mathrm{C}\right) ; \mathrm{T}_{45}=$ Piglet surface temperature 45 min after birth $\left({ }^{\circ} \mathrm{C}\right) ; \mathrm{T}_{60}=$ Piglet surface temperature $60 \mathrm{~min}$ after birth $\left({ }^{\circ} \mathrm{C}\right) ; \mathrm{T}_{120}=$ Piglet surface temperature $120 \mathrm{~min}$ after birth $\left({ }^{\circ} \mathrm{C}\right)$; TFS $=$ Time to first suckle $(\mathrm{min}) ; \mathrm{P}_{120}=$ Piglet weight after 120 min old $(\mathrm{kg})$. 

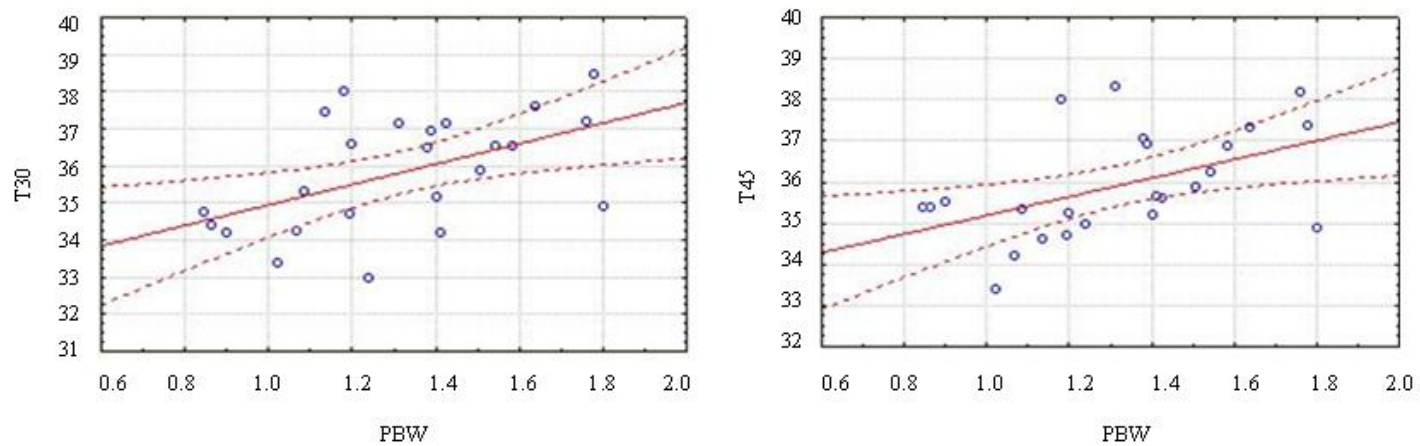

Figure 3. Correlations between piglet birth weight (PBW) and surface temperatures at 30 (T30) and 45 (T45) min after birth, with a confidence interval of $95 \%$.

newborn mammals, but both the extent of initial drop in body temperature and time required for subsequent recovery are highly variable. Newborn piglets are inadequately shielded, lacking of brown adipose tissue and depend on almost exclusively on shivering to thermogenesis for cold (Herpin et al., 2002).

At birth, piglets usually have sudden reduction in body temperature and the recovery of normal temperature of $39^{\circ} \mathrm{C}$ is achieved within the first 24 to $48 \mathrm{~h}$ after birth, being directly dependent on the temperature of their body weight and the moment he begins to suckle (Quesnel et al., 2012). However, excessive hypothermia due to adverse environmental conditions, low birth weight or reduced vitality can reduce the vigor and colostrum intake and lead, ultimately, death of the animal (Souza, 2007; Panzardi et al., 2013). By exposing newborn piglets to hypothermia, Lossec et al. (1998) observed that the body temperature and skin showed, rigorously, the same behavior, suggesting that even though the concentration of circulating catecholamine have increased during cooling of the body piglets were unable to reduce heat losses effectively through peripheral vasoconstriction.

When assessing connections between different physiological and behavioral measures (birth weight, birth hypoxia, latency between the first udder contact and first feeding) and connections with piglets' ability to overcome hypothermia early postnatal, Jensen et al. (2011) concluded

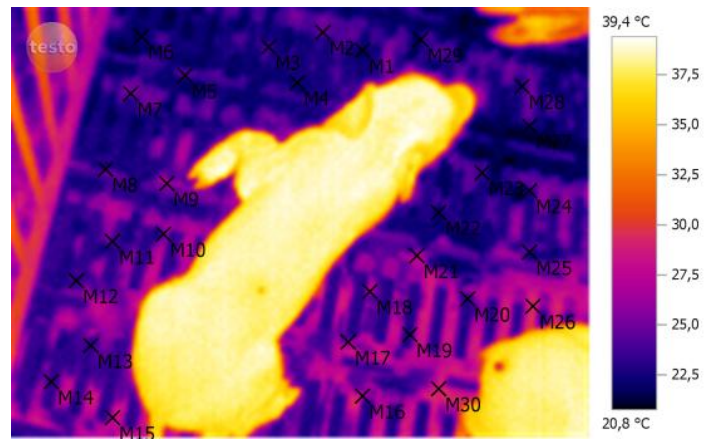

that birth weight is the most important factor in successful recovery from hypothermia postnatal. The correlation between birth weight and thermoregulation capacity of piglets in challenging situations by cold was also described in other researches (Herpin et al., 2004; Gondret et al., 2005; Baxter et al., 2008). Small piglets have higher surface area relative to the volume of the body in comparison with the large piglets, and these animals are, consequently, more prone to heat loss in a cold environment. Thus, small piglets are especially at increased risk since the heat loss per weight unit is inversely related to the size of the body. The low capability to retain heat is reflected by fact that each $1{ }^{\circ} \mathrm{C}$ reduced below the minimum critical temperature is associated with increased from $1.46 \mathrm{~kJ} \mathrm{~kg} \mathrm{k}^{-0.75} \mathrm{~h}^{-1}$ heat production, a value three times higher than in $35 \mathrm{~kg}$ pig (Herpin and Le Dividich, 1995). Differences in weight related to physiological maturity may be another possible explanation for the relationship between the success of thermoregulation and birth weight (Jensen et al., 2011).

Relating to birth weight and efficiency of thermoregulation, Jensen et al. (2011) and Herpin et al. (2004) suggested that there was a minimum birth weight close to $1,100 \mathrm{~g}$, and below that modern European breeds piglets have thermogenic capacity linearly impaired.

The average surface temperature of the floor in farrowing crates ranged from $24^{\circ} \mathrm{C}$ to $28^{\circ} \mathrm{C}$. (Figure 4). Considering that much of the heat loss by piglets at that

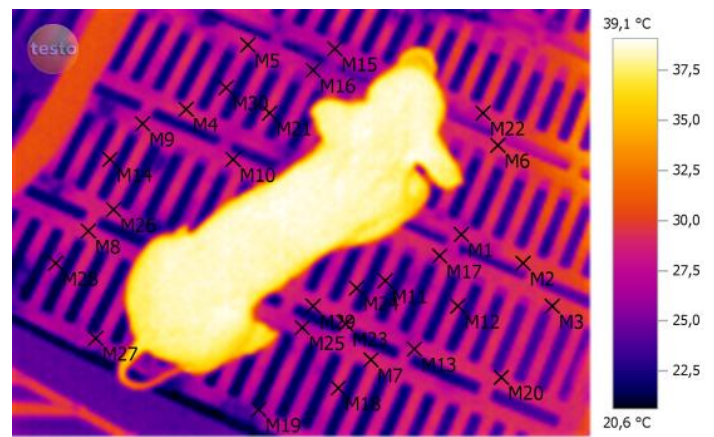

Figure 4. Thermography images of selected 30 points at birth and 15 min after birth to present the surface temperature of the floor of rear part of farrowing crates. 

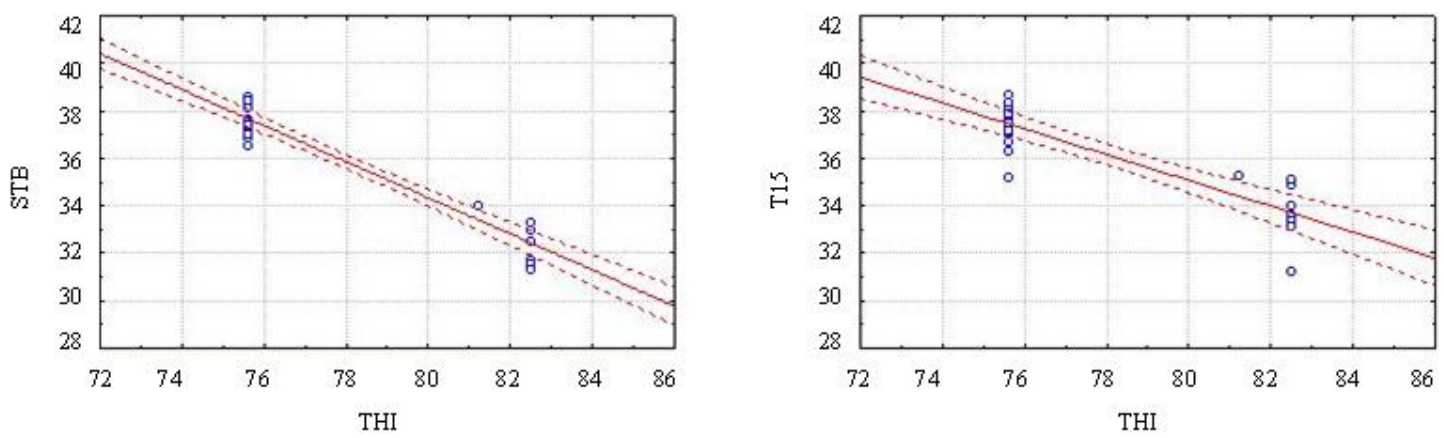

Figure 5. Correlations between temperature humidity index (THI) and the surface temperature at birth (STB) and 15 min after birth (T15), with a confidence interval of $95 \%$.

moment occurred by conduction, we realized the importance of management practices to minimize heat exchange between the neonates and the floor, such as the use of bedding.

Birth weight was negatively correlated with the time to first suckle and spent (TFS), suggesting that piglets with higher birth weight ingest colostrum faster than piglets with lower weight (Table 2), which was similar to that observed by Jensen et al. (2011).

The body energy stored at birth is present in the form of glycogen and fat. However, the available energy from glycogen and fat derivatives for newborn piglets is extremely low. Carbohydrates are the first and predominantly utilized by newborn pig and its use is significantly accelerated during exposure to cold (OrozcoGregorio, 2007) leading to the rapid depletion of glycogen (Pastorelli et al., 2009). The amount of body fat is also extremely low at birth, and most of them are not available for oxidation. Colostrum consumption provides to piglets large amounts of fat $(30 \%$ to $40 \%$ of total energy of colostrum) and, therefore, substantial changes thereby providing energy substrates for thermoregulation. Once piglets with low birth weight possess even smaller amounts of energy reserves and given their greater difficulty on ingest considerable amounts of colostrum special attention should be given to minimize these losses by hypothermia.

High correlation was found between birth weight and weight after two hours of life (P120), which was already expected since there was low variation between the weights of piglets in this period. Thus, the time to first suckle (TFS) also showed high negative correlation with the P120.
THI showed high negative correlations $(-0.824$ and $-0.815)(\mathrm{p}<0.01)$ with the surface temperature at birth (TNS) and at 15 min after birth (T15), indicating that the higher the THI the lower the surface temperatures of piglets in the first moments after birth (Table 2, Figure 5). This result shows that the ambient has a direct influence on piglet body temperature, since heat stressed sows may show physiological changes in an attempt to maintain thermal homeostasis, reflected during delivery, directly in the fetuses.

The piglets' temperature at birth was positively correlated with temperature at $15 \mathrm{~min}$ post-natal influencing consequently the temperatures in the interval of 45 to 120 min. Between 60 and 120 min after birth, there was an increase in the temperature of the animal, explaining the high positive correlation $(0.614)(\mathrm{p}<0.01)$ between these variables. This rapid recovery attempt in body temperature between one and two hours after birth may reflect good thermal conditions of the accommodation on the farrowing moment.

\section{Individual effect of the sow}

With the intention to evaluate individual effects of mothers on the surface temperature behavior of piglets and time to first feeding, females were considered as treatments. Piglets' birth weight showed no significant difference $(\mathrm{p}>$ $0.05)$. However, the piglets' surface temperatures from birth to $60 \mathrm{~min}$ were significantly different $(\mathrm{p}<0.05)$ for the different piglets from the sows, and the same equaled since 120 min after birth (Table 3).

A total of $25.71 \%$ of piglets showed surface temperature

Table 3. Variance analysis results (ANOVA) of piglet birth weight (PBW) and piglets surface temperatures at birth (STB), 15 (T15), 30 (T30), 45 (T45), 60 (T60), and 120 (T120) min after birth, between different sows

\begin{tabular}{lcccccccc}
\hline FV & GL & PBW & STB & T15 & T30 & T45 & T60 & T120 \\
\hline Block & 7 & 0.101 & 0.559 & 1.863 & 4.064 & 3.019 & 1.621 & 0.307 \\
Treatment & 3 & $0.184^{\text {ns }}$ & $48.926^{* *}$ & $26.543^{* *}$ & $10.401^{* *}$ & $9.699^{* *}$ & $2.824^{*}$ & $1.898^{\text {ns }}$ \\
Residue & 21 & 0.077 & 0.472 & 0.651 & 0.884 & 0.667 & 0.341 & 0.479 \\
VC\% & & 22.31 & 1.89 & 2.21 & 2.58 & 2.24 & 1.59 & 1.85 \\
\hline
\end{tabular}

* Significant $(\mathrm{p}<0.05),{ }^{* *}$ Significant $(\mathrm{p}<0.01) .{ }^{\mathrm{ns}}$ No significant by T Test. 
Table 4. Means of piglet birth weight (PBW) and piglets surface temperatures $\left({ }^{\circ} \mathrm{C}\right)$ at birth $(\mathrm{STB})$ and $15(\mathrm{~T} 15), 30(\mathrm{~T} 30), 45(\mathrm{~T} 45), 60$ (T60), and 120 (T120) min after birth between different sows

\begin{tabular}{lccccccc}
\hline Treatment & PBW & STB & T15 & T30 & T45 & T60 & T120 \\
\hline Sow 1 & $1.39^{\mathrm{a}}$ & $37.56^{\mathrm{a}}$ & $37.17^{\mathrm{a}}$ & $36.48^{\mathrm{ab}}$ & $36.59^{\mathrm{ab}}$ & $37.28^{\mathrm{a}}$ & $38.00^{\mathrm{a}}$ \\
Sow 2 & $1.03^{\mathrm{a}}$ & $37.16^{\mathrm{a}}$ & $37.41^{\mathrm{a}}$ & $37.77^{\mathrm{a}}$ & $37.70^{\mathrm{a}}$ & $36.58^{\mathrm{ab}}$ & $37.01^{\mathrm{b}}$ \\
Sow 3 & $1.27^{\mathrm{a}}$ & $37.71^{\mathrm{a}}$ & $37.68^{\mathrm{a}}$ & $35.94^{\mathrm{bc}}$ & $36.09^{\mathrm{bc}}$ & $36.55^{\mathrm{ab}}$ & $37.12^{\mathrm{ab}}$ \\
Sow 4 & $1.31^{\mathrm{a}}$ & $32.55^{\mathrm{b}}$ & $33.80^{\mathrm{b}}$ & $35.05^{\mathrm{c}}$ & $35.05^{\mathrm{c}}$ & $35.82^{\mathrm{b}}$ & $36.99^{\mathrm{b}}$ \\
\hline
\end{tabular}

* Means followed by the same letter in the column do not differ statistically among themselves by the Tukey test, at $5 \%$ probability.

below $35^{\circ} \mathrm{C}$ at birth, $20 \%$ between $35^{\circ} \mathrm{C}$ and $37^{\circ} \mathrm{C}$ and $54.29 \%$ higher than $37^{\circ} \mathrm{C}$, emphasizing that all those whose skin temperature at birth was below $35^{\circ} \mathrm{C}$ were from the same sow, which would characterize an individual effect of the mother.

Piglets born from the sow 4 showed the lowest surface temperature at birth $(\mathrm{p}<0.05)$, and hence lower temperatures at 15,30 , and 45 min post-natal, equaling to others after this period. In general, the piglets from other sows showed similar in the first two hours of life. As all the animals were kept and born in the same environment, there was no significant effect of birth weight of piglets between sows, it can be inferred the existence of genetic factors inherent to mother, which could affect piglets' thermoregulatory mechanisms (Table 4).

Jensen et al. (2011) also observed a strong effect of sow on piglets' rectal temperature at birth when studying factors that influence thermoregulation in neonatal pigs. However, this effect was no longer present at two hours after birth, similar to the results obtained in this study, in which the rectal temperature two hours after birth was not related to rectal temperature at birth, or with sow.

The cold stress at birth reduces the piglet strength, thereby reducing the amount of colostrum intake, and, therefore, nutrients which serve as an energy source for thermal regulation and the pig become lethargic and more likely to be crushed by the sow. This result indicates that the maintenance of homoeothermic and practice of early nutrition are of great importance for the survival of piglets. The permanent assistance at birth is a recommended practice and as the piglets are born, they must be clean and dry to reduce the loss of body heat, and avoid them to spend their few energy reserves in an attempt to maintain body temperature. Special attention should be offered to newborns with low birth weight, as they are more prone to hypothermia postnatal.

Considering that during farrowing, about $70 \%$ of piglet mortality occurs in the first week of life (Ferreira et al., 2007) and the caused are mostly by non-infectious problems such as crushing and starvation, which can be caused by exposure to cold. Thus, appropriate management practices can significantly reduce losses, and set in improvements in the profitability of the production system.

In practical terms, an additional source of heat must be offered to piglets in farrowing cages. However, they tend to stay close to their mothers and ignore this source of heat on the first day of life. Therefore, measures should be adopted to encourage the retention of piglets inside the creep in the periods in which they are not breastfed.

\section{IMPLICATIONS}

The piglet weight at birth interfere significantly in the behavior of its postnatal surface temperature and consequently in the time it takes to ingest colostrum. Heavier piglets at birth have lower temperature drop and the first intake of colostrum occurs more rapidly. Piglets with low birth weight require special attention to avoid losses due to hypothermia.

\section{REFERENCES}

Antunes, R. C. 2007. Planejando a reposição de reprodutores (macho e fêmea) e impacto sobre a eficiência reprodutiva da granja. Rev. Bras. Reprod. Anim. 31:41-46.

Baxter, E. M., S. Jarvis, R. B. D'Eath, D. W. Ross, S. K. Robson, M. Farish, I. M. Nevison, A. B. Lawrence, and S. A. Edwards. 2008. Investigating the behavioural and physiological indicators of neonatal survival in pigs. Theriogenology 69:773783.

Brown-Brandl, T. M., R. A. Eigengerg, J. A. Nienaber, and S. D. Kachman. 2001. Thermoregulatory profile of a newer genetic line of pigs. Livest. Prod. Sci. 71:253-260.

Damgaard, L. H., L. Rydhmer, P. Lovendahl, and K. Grandinson. 2003. Genetic parameters for within-litter variation in piglet birth weight and change in within-litter variation during suckling. J. Anim. Sci. 81:604-610.

Ferreira, R. A., J. Chiquieri, P. P. Mendonça, T. V. Melo, M. D. Cordeiro, and R. T. R. N. Soares. 2007. Comportamento e parâmetros fisiológicos de leitões nas primeiras 24 horas de vida. Ciênc. Agrotec. 31:1845-1849.

Gondret, F., L. Lefaucheur, I. Louveau, B. Lebret, X. Pichodo, and Y. Le Cozler. 2005. Influence of piglet birth weight on postnatal growth performance, tissue lipogenic capacity and muscle histological traits at market weight. Livest. Prod. Sci 93:137-146.

Herpin, P. and J. Le Dividich. 1995. Thermoregulation and the environment. In: The Neonatal Pig (Ed. M. Varley). Development and Survival. CAB International, Wallingford, pp. 57-98.

Herpin, P., M. Damon, and J. Le Dividich. 2002. Development of 
thermoregulation and neonatal survival in pigs. Livest. Prod. Sci. 78:25-45.

.Herpin, P., A. Vincent, and M. Damon. 2004. Effect of breed and body weight on thermoregulatory abilities of European (Pietrain $\times($ Landrace $\times$ Large White) $)$ and Chinese (Meishan) piglets at birth. Livest. Prod. Sci. 88:17-26.

Jensen, T., L. J. Pedersen, and E. Jorgensen. 2011. Hypothermia in neonatal piglets: Interactions and causes of individual differences. J. Anim. Sci. 89:2073-2085.

Lay Júnior D. C., R. L. Matteri, J. A. Carroll, T. J. Fangman, and T. J. Safranski. 2002. Preweaning survival in swine. J. Anim. Sci. 80:E74-E86.

Lima, A. L., R. F. M. Oliveira, J. L. Donzele, H. C. Fernandes, P. H. R. F. Campos, and M. V. L. Antunes. 2011. Resfriamento do piso da maternidade para porcas em lactação no verão. Rev. Bras. Zootec. 40:804-811.

Lossec, G., P. Herpin, and J. Le Dividich. 1998. Thermoregulatory responses of the newborn pig during experimentally induced hypothermia and rewarming. Exp. Physiol. 83:667-678.

Malmkvist, J., L. J. Pedersen, B. M. Damgaard, K. Thodberg, E. Jorgensen, and R. Labouriau. 2006. Does floor heating around parturition affect the vitality of piglets born to loose housed sows? Appl. Anim. Behav. Sci. 99:88-105.

Manno, M. C., R. F. M Oliveira, J. L. Donzele, A. S. Ferreira, W. P. Oliveira, K. R. S. Lima, and R. G. M. Vaz. 2005. Efeito da temperatura ambiente sobre o desempenho de suínos dos 15 aos 30 kg. R. Bras. Zootec. 34:1963-1970.

Mendonça, A. B. 2010. Conforto térmico em suínos visando melhoria na produção e qualidade do produto final. Postgraduate Monography, Universidade Castelo Branco, Campinas, SP, Brazil.

Merks, J., D. Ducro-Steverink, and H. Feitsma 2000. Management and genetic factors affecting fertility in sows. Reprod. Domest. Anim. 35:261-266.

Mount, L. E. 1959. The metabolic rate of the new-born pig in relation to environmental temperature and to age. J. Physiol. 147:333-345.

Orozco-Gregorio, H., D. Mota-Rojas, M. Alonso-Spilsbury, M. Gonzalez-Lozano, M. Trujillo-Ortega, S. A. Olmos-Hernandez, P. Sanchez-Aparicio, R. Ramãrez-Necoechea, R. HernandezGonzalez, R. Uribe-Escamilla, and D.Villanueva-Garcia. 2007. Importance of blood gas measurements in perinatal asphyxia and alternatives to restore the acid base balance status to improve the newborn performance. Am. J. Biochem. Biotechnol. 3:131-140.
Pandorfi, H., I. J. O. Silva, D. J. Moura, and K. B. Sevegnani. 2005. Microclima de abrigos escamoteadores para leitões submetidos a diferentes sistemas de aquecimento no período de inverno. Rev. Bras. Eng. Agric. Amb. 9:99-106.

Panzardi, A., T. Bierhals, A. P. G. Mellagi, M. L. Bernardi, F. P. Bortolozzo, and I. Wentz. 2009. Survival of piglets according to physiological parameters at birth. In: Proceedings of the 8th International Conference on Pig Reproduction (Banff, Canada). (in press).

Panzardi, A., M. L. Bernardi, A. P. Mellagi, T. Bierhals, F. P. Bortolozzo, and I. Wentz. 2013 Newborn piglet traits associated with survival and growth performance until weaning. Prev. Vet. Med. 110:206-213.

Pastorelli, G. M., M. Neil, and I. Wigren. 2009. Body composition and muscle glycogen contents of piglets of sows fed diets differing in fatty acids profile and contents. Livest. Sci. 123:329-334.

Quesnel, H., C. Farmer, and N. Devillers. 2012. Colostrum intake: Influence on piglet performance and factors of variation. Livest. Sci. 146:105-114.

Quiniou, N., J. Dagorn, and D. Gaudré D. 2002. Variation of piglet's birth weight and consequences on subsequent performance. Livest. Prod. Sci. 78:63-70.

SAS Institute Inc. 2001. SAS/STAT user's guide: Version 6. 6th ed. SAS Institute Inc., Cary, North Carolina.

Sorensen, D., A. Vernersen, and S. Andersen. 2000. Bayesian analysis of response to selection: A case study using litter size in Danish Yorkshire pigs. Genetics 156:283-295.

Souza, P. 2007. O frio e sua influência no comportamento do suíno. Porkworld. Access: http://editora-animalworld.com.br/ porkworld/artigos/post/o-frio-e-suainfluencia-nocomportamento-do-suino_10086.

Tuchscherer, M., B. Puppe, A. Tuchscherer, and U. Tiemann. 2000. Earley identification of neonates at risktraits of newborn piglets with respect to survival. Theriogenology 54:371-388.

Van Rens, B. T. T. M., G. De Koning, R. Bergsma, and Van Der Lende T. 2005. Preweaning piglet mortality in relation to placental efficiency. J. Anim. Sci. 83:144-151.

Yan, P. S. and S. Yamamoto. 2000. Relationship between thermoregulatory responses and heat loss in piglets. J. Anim. Sci. 71:505-509. 